\title{
Näkymiä Atlantin takaa
}

Miten maankäytön suunnittelun

järjestelmät voivat tukea strategisuutta kaupunkisuunnittelussa?

Hanna Mattila

Tarkastelen tässä artikkelissa maankäytön suunnittelun järjestelmiä Yhdysvalloissa. Keskityn järjestelmien luomiin edellytyksiin kaupunkisuunnittelun strategisuudelle, jota Yhdysvalloissa tukee etenkin jako yleispiirteisen suunnittelun ja kaavoituksen (zoning) välillä. Tarkasteluni tarkoituksena on paitsi tarjota uutta tietoa yhdysvaltalaisesta suunnittelusta järjestelmätasolla, myös avata uusia näkymiä suomalaiseen, maankäyttöä ohjaavan lainsäädännön kokonaisuudistuksen kirvoittamaan keskusteluun. Tässä keskustelussa yleispiirteisen suunnittelun strategisuuden vahvistaminen on ollut keskeinen teema, mutta strategisuuden määrittely ja paikantaminen on osoittautunut vaikeaksi ja kiistanalaiseksi oman moniportaisen ja hierarkkisesti tarkentuvan järjestelmämme puitteissa.

Avainsanat: maankäytön suunnittelu, strateginen suunnittelu, suunnittelujärjestelmä, Yhdysvallat, zoning

\section{Johdanto}

Suunnittelujärjestelmiä ja niitä määrittävää lainsäädäntöä kehitettäessä ja uudistettaessa haetaan usein esimerkkejä ja vertailukohtia ulkomailta siitäkin huolimatta, että muualta lainattuja järjestelmän osia ei yleensä voi sellaisenaan sovittaa lähtökontekstista poikkeavaan juridiseen, hallinnolliseen, poliittiseen, taloudelliseen ja kulttuuriseen viitekehykseen (Healey, 2012; Healey \& Upton 
[toim.], 2010). Muualta ei kannatakaan ensisijaisesti hakea konkreettisia suunnittelun työkaluja, vaan ulkomaisia esimerkkejä on hyödyllistä tarkastella siksi, että ne tuovat uusia näkökulmia omaan järjestelmäämme ja auttavat meitä ymmärtämään paremmin oman järjestelmämme ja sen toimintaympäristön ominaispiirteitä (Hirt, 2014, s. 12). Tämä on välillisesti hyödyllistä myös järjestelmien ja yksittäisten työkalujen kehittämisen näkökulmasta. Myös nyt käynnissä olevan maankäyttö- ja rakennuslain (132/1999) kokonaisuudistusta on tuettu katsauksilla useisiin eurooppalaisiin suunnittelujärjestelmiin, joista on pyritty löytämään uusia tulokulmia yksinkertaisemman, yksityiskohtaisella tasolla joustavamman ja strategisella tasolla ohjaavamman suunnittelujärjestelmän kehittämiseen (Lehtovuori ym., 2019). Erityisesti katsaukset pohjoismaisiin ja mannereurooppalaisiin järjestelmiin puoltavat hyvin paikkaansa jopa silloin, kun etsitään omaan ympäristöömme sopivia uusia suunnittelun työvälineitä ja prosesseja, koska erot suomalaiseen yhteiskuntaan ja kulttuuriin eivät ole yleensä kovin mittavia. Myös Englannin kehittäjäjohtoinen suunnittelujärjestelmä on ollut jonkin verran esillä Suomessa, vaikka se poikkeaa etenkin oikeudellisilta lähtökohdiltaan oleellisesti niin suomalaisesta kuin mannereuroopalaisistakin suunnittelujärjestelmistä (Maisala, 2014; 2015; ks. myös Lehtovuori ym., 2019). Brittiläisiä järjestelmiä voi kutsua harkintaan perustuviksi (discretionary), kun taas mannereurooppalaisia ja pohjoismaisia järjestelmiä kutsutaan sääntelyyn perustuviksi (regulatory) (Booth, 1996; 2007). Käytännössä siis Manner-Euroopassa pääsääntöisesti luotetaan sitoviin kaavoihin, kun taas brittiläisessä mallissa hankkeita arvioidaan tapauskohtaisesti niiden omiin ansioihin perustuen, jolloin kaavat tai muut suunnitelmat eivät kokonaan sido hankkeen lupaharkinnan lopputulosta (Booth, 1996; ks. myös Albrechts, 2004; European Commission, 1997). Brittiläisessä järjestelmässä näkyykin tässä suhteessa tapaoikeuden (common law) perinne, jossa kirjoitettu laki ei ohjaa yhtä tiukasti viranomaisten ja oikeuden harkintavaltaa kuin mannereurooppalaisessa perinteessä.

Tässä artikkelissa luon katsauksen Yhdysvaltojen suunnittelujärjestelmiin Yhdysvaltojen Minnesotassa tutkijana, opettajana ja suunnittelusta kiinnostuneena kaupunkilaisena viettämieni kahden lukuvuoden kokemusten innoittamana. Yhdysvaltaisia järjestelmiä ei tunneta Suomessa kovin hyvin, eivätkä edes yksityisen sektorin edustajat ole juurikaan tuoneet niitä suomalaiseen keskusteluun, vaikka niitäkin pidetään kehittäjämyönteisinä. Ne eivät ole kuitenkaan muodollisesti kehittämisjohtoisia brittijärjestelmien tavoin, vaan pääsääntöisesti kaavajohtoisia, kuten meidänkin järjestelmämme. Tästä yhteneväisyydestä huolimatta Yhdysvallat ei ehkä ole suunnittelijan näkökulmasta maa, joka tulee ensinnä mieleen silloin kun etsitään virikkeitä ja keskustelunherättäjiä Suomen maankäyttöä ohjaavan järjestelmän uudistukseen - onhan 
järjestelmän puitteissa syntynyt paljon fyysisesti ja toiminnallisesti hajautunutta sekä sosiaalisesti segregoitunutta kaupunkirakennetta, joka usein jää kauas niistä kriteereistä, joita Suomessa edellytetään ekologisesti, taloudellisesti, kulttuurisesti ja sosiaalisesti kestävältä ympäristöltä. Kulttuuristen stereotypioiden ja ennakkoluulojen ei tulisi kuitenkaan antaa liikaa ohjata kiinnostavien vertailukohtien etsintää, sillä suunnittelujärjestelmät ja niitä kehystävä lainsäädäntö ovat monitahoisia ja saattavat siten yllättää vertailijan yksityiskohdillaan (Alterman, 2011). Yhdysvaltojen järjestelmissä on nähdäkseni piirteitä, jotka auttavat suunnittelukäytäntöjä vastaamaan monitahoisiin kaupunkiongelmiin tehokkaasti, mikäli tähän on poliittista tahtoa.

Koska suomalaisen suunnittelujärjestelmän uudistuksen yksi keskeisimmistä tavoitteista on ollut strategisempiin suunnitteluotteisiin kannustava järjestelmä, keskityn tarkastelussani siihen, miten yhdysvaltalaiset järjestelmät tukevat suunnittelun strategisuutta. Pohjois-Amerikka on strategisen suunnittelun teorian alkukoti, joten ei liene yllättävää, että Yhdysvalloissa maankäytön suunnittelu näyttäytyy ainakin järjestelmätasolla monella mittapuulla mitattuna hyvin strategisena (ks. esim. Bryson \& Schively Slotterback, 2017). Suunnittelukäytännöt eivät tietenkään suoraan seuraa järjestelmästä, mutta kokemukseni on, että strategisuus näkyy yhdysvaltalaisessa yleispiirteisen suunnittelun käytännöissä etenkin eri toimijoiden näkökulmasta selkeästi hahmottuvina suunnittelun päämäärävalintojen paikkoina ja monipuolisena valikoimana keinoja päämäärien toteuttamiseen. Tässä artikkelissa en kuitenkaan reflektoi omia kokemuksiani, vaan menetelmänäni on tarkastella yhdysvaltaisia suunnittelujärjestelmiä käsittelevää kirjallisuutta sekä järjestelmiä määrittävää lainsäädäntöä ja muita virallislähteitä strategisen suunnittelun teorioiden valossa sekä vertailla yhdysvaltalaisten järjestelmien strategisuutta ilmentäviä ominaisuuksia niihin institutionaalisiin ratkaisuihin, joita suomalaisessa keskustelussa on tarjottu suunnittelun strategisuuden parantamiseksi. Tässä nojaan paitsi suunnitteluteoriaan, myös suunnittelujärjestelmien vertailevan tutkimuksen perinteeseen ${ }^{1}$ (ks. esim. Nadin, 2012; Nadin \& Stead, 2013). Tarkoituksenani ei ole

\footnotetext{
1 Vertailevalla suunnittelujärjestelmien tutkimuksella ei ole yhtenäistä metodologiaa, mutta se on silti vakiintunut tutkimusperinne, jossa pyritään tuomaan esiin joko järjestelmien (tai niiden osien) eroja tai samankaltaisuuksia, luomaan typologioita järjestelmistä tai niiden osista ja hahmottamaan ideaalityyppejä (ks. esim. Getimis, 2012). Vertailevan tutkimuksen käytännön hyödyt voivat olla monenlaisia. Samankaltaisten järjestelmien välisen vertailun pohjalta voidaan esimerkiksi löytää uusia suunnittelun työkaluja ja toimintatapoja, kun taas keskenään poikkeavien järjestelmien vertailu saattaa tuottaa paremmin ymmärrystä järjestelmien ominaisluonteesta, esimerkiksi niiden vahvuuksista ja heikkouksista. Suunnittelujärjestelmien vertailuissa lainataan usein menetelmiä muilta tieteenaloilta, kuten oikeusvertailusta, vaikka oikeusvertailunkaan menetelmistä ei vallitse yksimielisyyttä tutkijoiden keskuudessa (ks. esim. Husa, 2010). Juridisen kehyksen lisäksi hallinnollisten perinteiden vertailu on myös yleensä keskeisessä osassa vertailevassa järjestelmätutkimuksessa (ks. esim. Newman \& Thornley, 1996). Koska suunnittelujärjestelmät kehittyvät ja toimivat aina jossain tietyssä yhteiskunnallisessa ympäristössä, niiden vertailussa tukeudutaan toisinaan myös erilaisiin vertailevan sosiologian menetelmiin (Othengrafen \& Galland, 2019).
} 
tuottaa ehdotuksia oman lainsäädäntömme uudistamiseksi eikä pyrkiä tuomaan omaan järjestelmäämme elementtejä erilaisessa kulttuurisessa ympäristössä kehittyneestä järjestelmästä. Sen sijaan pyrin tuomaan vertailun kautta esiin uusia näkökumia niihin moninaisiin ongelmiin ja kiistoihin, joita strategisempaan suunnitteluotteeseen paremmin kannustavan suunnittelujärjestelmän kehittäminen on herättänyt Suomessa.

Yhdysvaltalaisessa suunnitteluperinteessä strategisuuden kulmakivi on strategisen ja toteuttavan tason suunnittelun eriyttäminen, joka toteutuu ennen kaikkea yleispiirteisen suunnittelun ja kaavoituksen (zoning) tehtävien jaon muodossa. Vaikka brittijärjestelmien tapaan myös yhdysvaltalaiset järjestelmät tukeutuvat tapaoikeuteen, yksityiskohtaisen suunnittelun tasolla Yhdysvalloissa on keskiössä joustavan harkinnan sijaan sitova sääntely tyypillisesti zoning-tyyppisen kaavoituksen keinoin. Sen tarkoituksena on tuottaa mahdollisimman yksitulkintaisia kaavoja, jotta maanomistajat, kehittäjät ja rakentajat voivat ennakoida, millaiset hankkeet ovat toivottuja ja tulevat menestymään lupavaiheessa (Booth, 1996, s. 6). Tällaisen periaatteessa joustamattoman ja tulevaisuuden epävarmuuksille sokean kaavoituksen vastapainona Yhdysvalloissa on yleispiirteinen suunnittelu, joka perustuu tyypillisesti pitkän tähtäimen visiointiin, vahvoihin päämäärävalintoihin, vuorovaikutukseen osallisten kanssa sekä toteutuksen ohjelmointiin ja aikataulutukseen. Se vastaa myös eurooppalaista strategisen "spatiaalisen suunnittelun" ihannetta siltä osin, että se tuo hallinnon eri sektoreita yhteen, vaikka eurooppalaisessa spatiaalisen suunnittelun keskustelussa strategisuus paikantuu usein nykyään ylikunnalliselle tasolle (ks. esim. Albrechts 2004; Healey 2007), kun taas Yhdysvalloissa järjestelmät tyypillisesti painottavat paikallisen tason suunnittelun strategisuutta.

\section{Strategisen maankäytön suunnittelun puitteet Yhdysvalloissa} Yhdysvalloissa liittovaltiotason ohjaus on maankäyttöasioissa hyvin vähäistä. Maankäytön suunnittelun valtakunnantasoiset suuntaviivat ovat pitkään perustuneet 1920-luvulla luotuihin ohjeluontoisiin Standard State Zoning Enabling Actiin ja Standard City Planning Enabling Actiin (American Planning Association, 2020; Elliot, 2008, s. 15-18). Uudempaa yhtenäistä, maankäyttöä ohjaavaa lainsäädäntöä yritettiin turhaan saada aikaan 1970-luvun alkupuolella, eikä aiheeseen ole sen jälkeen palattu valtakunnan politiikassa (salkin, 20o9; Tarlock, 2014). Tästä johtuen suunnittelujärjestelmissä on vaihtelua osavaltioiden välillä.

Perustuslailla ja sen takaamalla omaisuuden suojalla on kuitenkin ollut keskeinen merkitys kaikkien osavaltioiden suunnittelujärjestelmien muotoutumisessa. Kun paikallishallinnon sääntelyn on katsottu olleen törmäyskurssilla maanomistajien oikeuksien kanssa, yhteentörmäyksiä on puitu oikeudessa, 
ja Yhdysvaltain korkeimman oikeuden tehtäväksi on lopulta jäänyt linjata ennakkotapausten kautta, missä määrin ja miten paikallinen hallinnon taso saa perustuslain puitteissa säännellä maankäyttöä alueellaan (Cullingworth \& Caves, 20og; Hirt, 2014). Tapaoikeuden perinne näkyy muutoinkin Yhdysvalloissa oikeusistuinten keskeisenä merkityksenä suunnittelujärjestelmän kehityksessä (Booth, 1996; Cullingworth \& Caves, 2009). Yhdysvalloissa lainsäätäjällä ei ole siis yhtä laajaa vaikutusvaltaa suunnittelujärjestelmän muotoutumiseen kuin Manner-Euroopassa (Booth, 1996). Mannereurooppalaista toimintaympäristöä lähellä ovat myös pohjoismaiset järjestelmät, joissa lainsäätäjän vallan voi kuitenkin ajatella olevan hieman vähäisempi kuin mannereurooppalaisen oikeudellisen perinteen maissa, sillä pohjoismaissa kirjoitettu laki ei pyri olemaan yhtä kokonaisvaltaista ja aukotonta kuin germaanis-romaanisessa perinteessä, ja se sisältää näin ollen siis hieman enemmän liikkumavaraa sekä viranomaisille että oikeusistumille (Husa, 2012).

Siinä missä Yhdysvalloissa liittovaltiotason merkitys on vähäinen maankäytölle ja sen suunnittelulle, useimmilla osavaltioilla on näihin toimintoihin kohdistuvaa lainsäädäntöä, jossa tosin päätäntävalta maankäyttöasioissa on perinteisesti siirretty hyvin pitkälti paikallistasolle (Cullingworth \& Caves, 2009; Hirt, 2014). Osavaltioiden kiinnostus maankäyttökysymyksiä kohtaan on kuitenkin kasvanut jatkuvasti 1970-luvulta lähtien, koska paikallishallinnon edustajilla on harvoin ollut mielenkiintoa ratkaista niitä ongelmia, joita paikalliset maankäyttöratkaisut ovat aiheuttaneet seudullisella tai osavaltion tasolla. Osavaltioiden lainsäädännössä on puututtu muun muassa osavaltiotasoisina pidettyihin luonnonvarakysymyksiin ja kulttuuriperinnön suojelemiseen, mutta myös moniin seututason huomiota vaativiin ilmiöihin kuten liikennejärjestelmien suunnitteluun ja kaupunkiseutujen väestönkasvun ohjaamiseen siten, että yhdyskuntarakenteen hajautuminen pysyisi hallinnassa. (Cullingworth \& Caves, 20og.) Jotkut osavaltiot ovat lainsäädännössään edellyttäneet kaupunkiseuduilta seututasoista suunnittelua. Näistä kuuluisin on Oregon, jonka "Urban Growth Boundary" -toimintapolitiikasta on haettu osviittaa myös suomalaiseen kaupunkiseutusuunnitteluun (Kalliomäki, 2018). Oregonin Portlandin kaupunkiseudulla muun muassa kasvun hallinnassa ja ohjaamisessa laajaa valtaa käyttää Yhdysvaltain ainoa vaaleilla valittu metropolivaltuusto (sullivan, 2014). Myös Minnesota vaatii osavaltion pääkaupungin Saint Paulin ja Minneapolisin muodostaman kaksoiskaupungin ympärille muodostuvan kaupunkiseudun suunnittelua kuntien yhteisessä päätöksentekoelimessä Metropolitan Councilissa, joka tosin ei ole vaaleilla valittu elin kuten Portlandin kaupunkiseudun Metro Council, mutta jonka muodollinen valta maankäyttöasioissa on laajempi kuin Portlandin metropolivaltuustolla (Taylor, 2019; ks. myös Bengston, Fletcher \& Nelson, 2004). 
Vaikka malliesimerkit kaupunkiseutujen strategisesta suunnittelusta ovat olleet vähissä Yhdysvalloissa, kaupunkien yleispiirteinen suunnittelu näyttäytyy monissa osavaltioissa hyvin strategisena ainakin paperilla. Strategisuudelle on esitetty tutkimuskirjallisuudessa monia kriteerejä-jopa niin monia, että jotkut ovat kyseenalaistaneet koko käsitteen analyyttisen ja normatiivisen hyödyllisyyden (Mazza, 2013). Yleisellä tasolla strategisuus on suunnittelun tehostamista jakamalla se yhtäältä pitkän tähtäimen tavoitteisiin, joiden täytyy olla paitsi ohjaavia, myös riittävän joustavia epävarmaa tulevaisuutta kohden kuljettaessa, ja toisaalta suunnittelun toteuttavaan tasoon, jolla täsmennetään keinot valittujen tavoitteiden saavuttamiseksi (ks. esim. Mintzberg, 1994; Kaufman \& Jacobs, 1987; Bryson, 1988). Tämä jako näkyy Yhdysvalloissa järjestelmätasolla selkeästi. Jako strategisen ja toteuttavan suunnittelun tason välillä ei kuitenkaan voi olla staattinen ja ehdoton. Suunnitteluteoriassa on tunnistettu jo Amitai Etzionin (1967) klassisesta "mixed scanning" -mallista alkaen, että toteutusaskeleiden kautta saadaan tärkeää toimintaympäristön muutoksiin liittyvää tietoa, jota kannattaa käyttää strategisten, pitkän tähtäimen valintojen tarkentamisessa tai korjaamisessa (ks. myös Mäntysalo ym., 2019). Monet strategisen suunnittelun variaatiot painottavat myös laajapohjaista ja osallistavaa päätöksentekoa strategisia valintoja tehtäessä, jotta päätösten laatu ja oikeutettavuus paranisivat ja toimijat sitoutuisivat päätöksiin, mikä tosin voi olla osittain ristiriidassa strategisuuteen sisältyvien tehokkuusvaatimusten kanssa (ks. esim. Albrechts, 2004; Healey, 2007). Lisäksi keskeisenä strategisuuden kriteerinä on pidetty eri hallinnon sektorien toimintaohjelmien nivomista yhteen (esim. Albrechts, Healey \& Kunzmann, 2003; Bryson, Crosby \& Stone, 2006), mutta tätä kriteeriä on puolestaan pidetty osittain ristiriitaisena valikoivan tavoitteiden asettamisen vaatimuksen kanssa (Ziafati Bafarasat, 2015). Strategisuus voi siis toteutua suunnittelussa monin eri tavoin eri ympäristöissä (Albrechts, 2004; Bryson, 2001, 2003; Friedmann, 2004), ja tilannekohtainen tasapainottelu eri strategisuuden aspektien välillä on aina tarpeen.

Yhdysvaltalaisen maankäytön suunnittelun kokonaisuudessa strategisuuden lähtökohtana on ennen kaikkea erottelu strategisen yleispiirteisen suunnittelun ja suunnitelmien toteutuksen välillä. Toteuttavalla tasolla kaavoituksella (zoning) on keskeinen tehtävä, ja se on huomattavasti yksipuolisempaa kuin suomalainen asemakaavoitus. Yleispiirteinen suunnittelu puolestaan nojaa monipuolisiin ja sektorienvälisiin kokonaisvaltaisiin suunnitelmiin. 


\section{Zoning - onko se suunnittelua?}

Yhdysvaltalaisen maankäytön suunnittelun ytimen muodostaa zoning-tyyppinen kaavoitus ${ }^{2}$, joskin monet suunnittelututkijat korostavat, ettei zoning ole lainkaan suunnittelua, vaan osa suunnitelmien täytäntöönpanoa (cullingworth \& Caves, 20og, s. 134-135; Tarlock, 2014). Yhdysvaltalaisen suunnittelun historialliset alkujuuret ovat kuitenkin zoningissa, jonka katsotaan tulleen Yhdysvaltoihin Saksasta, mutta omaksuneen Yhdysvalloissa olemuksen, joka poikkeaa ratkaisevasti eurooppalaisesta kaavoituksesta (Hirt, 2012; 2014; Tarlock, 2014). Zoning-sääntöjen ydin on rajatuilla vyöhykkeillä sallittujen toimintojen, rakennustehokkuuksien ja yleensä myös rakennusten sallittujen korkeuksien ja massoittelun perussääntöjen sitova määrittely. Nämä ovat siis samoja seikkoja, jotka Suomessa määritellään asemakaavassa. Zoning on kuitenkin pelkistetysti vain tätä; tonttijakokin määritellään tyypillisesti eri asiakirjassa (subdivision ordinance) ja kaupunkikuvalliset seikat yleensä lähiympäristön suunnitteluohjeissa (design guidelines). Zoning-määräykset sääntelevät ja rajoittavat rakentamista, eikä niihin yleensä pyritä lainkaan sisällyttämään suunnittelun luovaa ja vaihtoehtoisia tulevaisuuksia kartoittavaa aspektia (Hirt, 2014, s.6). Koska zoning-sääntöjen halutaan olevan mahdollisimman selkeitä, mutta vyöhykkeiden sisällä on usein pientä vaihtelua rakentamisen lähtökohtien suhteen, poikkeamismenettelyille on omat työkalunsa ja niitä myös käytetään yleisesti (Elliot, 2008; ks. myös Alterman, 2011).

Zoningilla on huono maine kriittisissä tutkijapiireissä, koska sen on katsottu aina olleen ensisijaisesti keino turvata omaisuuden arvoa siitäkin huolimatta, että se on rajoittanut maanomistajien mahdollisuuksia käyttää omaisuuttaan ja että sitä on näin ollen toisaalta aikoinaan arvosteltu myös Yhdysvaltoihin sopimattomana vasemmistolaisena käytäntönä (Hirt, 2014, s. 138, 142, 149-156). Zoning otettiin käyttöön 190o-luvun alussa kaupungeissa, joissa kasvava teollisuus ja kaupalliset toiminnot tuottivat asumiskäytössä olevien kiinteistöjen arvoa uhkaavia kielteisiä ulkoisvaikutuksia (cullingworth \& caves, 2009, s. 65). Toisinaan myös kaupunkikuvakysymykset olivat tuolloin keskeisiä, vaikka niiden merkitys hiipui myöhemmin (Moga, 2017). New Yorkissa, missä laadittiin Yhdysvaltojen tiettävästi maan ensimmäinen kokonaisvaltainen zoning-järjestys vuonna 1916, haluttiin säännellä paitsi pilvenpiirtäjien korkeuksia myös niiden arkkitehtonista muodonantoa siten, etteivät tornit varjostaisi kohtuuttomasti katutilaa ja ympäröiviä rakennuksia (Weiss, 1992, s. 88-89).

Zoning vakiinnutti asemansa monissa Yhdysvaltojen kaupungeissa 1920luvun aikana, ja myös sen valtakunnallista ohjausta kehitettiin, missä alun

2 Vaikka zoningia pidetään keskeisenä osana yhdysvaltalaisia suunnittelujärjestelmiä, sitä ei käytetä aivan kaikkialla Yhdysvalloissa. Poikkeuksista kuuluisin on Texasin Houston. Vaikka Houstonia pidetään usein esimerkkinä vapaiden markkinoiden tuottamasta kaupunkirakenteesta, maankäyttöä säännellään sielläkin muiden työkalujen avulla (Qian, 2010). 
perin vuonna 1924 laadittu ja kaksi vuotta myöhemmin uudistettuna versiona julkaistu Standard State Zoning Enabling Act oli keskeisessä osassa (Elliot, 2008, s. 15). Tuolloin oli kuitenkin vielä epäselvää, oliko kaavoitus perustuslain sallimaa viranomaisen vallankäyttöä. Korkeimman oikeuden päätös Euclid v. Ambler -tapauksessa vuonna 1926 toi tähän ratkaisun. Tapauksessa Ambler Realty oli haastanut oikeuteen Ohiossa, Clevelandin esikaupunkialueella sijainneen Euclidin kunnan, joka puolestaan oli kaavoituksella estänyt Ambler Realtya käyttämästä maaomaisuuttaan teolliseen tuotantoon. Kunta oli kaavoittanut alueelle omakotitaloasumista, ja kunnan kanta oli, että teolliset toiminnot olisivat olleet haitallisia yleiselle terveydelle, turvallisuudelle ja hyvinvoinnille. Pitkän prosessin jälkeen ja alemman oikeusasteen jo kumottua Euclidin kunnan zoning-järjestyksen korkein oikeus taipui tukemaan kunnan näkemystä. Kaava todettiin lailliseksi, ja tämä ennakkotapaus vahvisti yleisesti, että kuntien kaavoitustoimet olivat perustuslain mukaista toimintaa. (Cullingworth \& Caves, 2009, s. 72-74; Hirt, 2014, s. 34.)

Yhdysvaltalaiset ovat olleet poikkeuksellisen tehokkaita eriyttämään toimintoja zoning-määräysten avulla, vaikka Euroopassakin toimintoja toki ryhdyttiin eriyttämään erityisesti vuoden 1933 CIAMin funktionalistisen Ateenan julistuksen seurauksena. Euroopassa toimintojen synergiasta elinvoimansa ammentavilla urbaaneilla ympäristöillä on kuitenkin pitkä perinne, ja toimintojen eriyttämisen ylilyönnit voitiin ainakin osittain välttää modernistisen kaupunkisuunnittelun kulta-aikanakin. Yhdysvalloissa zoning sen sijaan tunnetaan etenkin yksitoimintoisten omakotitalolähiöiden valtavirtaistumisen moottorina, mistä jo Euclidin tapaus oli edustava esimerkki. Koska zoningin avulla on usein suljettu pois mahdollisuus muihin kuin yhden perheen taloihin, sitä on pidetty myös keinona suojella omakotitaloalueita ei-toivotuilta asukkailta, mikä puolestaan on edistänyt kaupunkialueiden segregaatiota (Hirt, 2014, s. 167-17; ks. myös Booth, 1996, s. 4). Epätoivottujen asukasryhmien poissulkemisesta zoningin keinoin on kiistelty oikeudessa monissa yhteyksissä 1970-luvulta alkaen, ja vaikka tällaiset käytännöt on usein todettu lainvastaisiksi, niihin on silti ollut käytännössä vaikea puuttua (Cullingworth \& Caves, 2009, s. 111, 284-289).

Vaikka zoning on ollut Yhdysvalloissa jatkuvan kritiikin kohteena, kritiikki ei useinkaan ole kohdistunut zoningin olemassaoloon, vaan usein esimerkiksi siihen, että zoning-määräyksillä käytännössä usein eliminoidaan kaupunkimaisen, monitoimintoisen ja moninaisia asumismuotoja sallivamman ympäristön mahdollisuudet (Elliot, 2008; Hirt, 2012, 2014; Tarlock, 2014). Tutkimuskirjallisuudessa on myös arvosteltu zoning-käytäntöjen markkinareaktiivisuutta, mutta tämäkään kritiikki ei kohdistu niinkään järjestelmään, vaan kiinteistösijoittamista ja -kehittämistä kestävän kehityksen kustannuksella suosivaan asenneilmapiiriin 
ja suunnittelukulttuuriin (cullingworth \& Caves, 2009; Hirt, 2014). Vaikka Yhdysvalloissa kehittäminen tapahtuu lähes aina yksityisellä maalla, julkinen sektori vastaa pitkälti infrastruktuurin ja palveluiden tuottamisesta (cullingworth \& Caves, 2009, s. 139-152). Näin ollen yksityisen sektorin aloitteisiin kritiikittömästi vastaava "spot zoning" on ongelma paitsi ekologisen myös taloudellisen kestävyyden kannalta.

Toisaalta Yhdysvalloissa käytetään zoningin ohella ohjauskeinona myös muun muassa kehittämismaksuja (impact fee), joilla kunnat voivat periä maanomistajilta takaisin infrastruktuurin ja julkisten palvelujen tuottamisen vaatimat kulut, joita uusi rakentaminen aiheuttaa (Peddle \& Lewis, 1996). Kunnat voivat myös ohjata rakentamisen sijoittumista haluamaansa suuntaan määrittämällä kehittämismaksut niin, että yhdyskuntarakenteen kannalta edullisilla vyöhykkeillä maksut ovat pienempiä kuin epäedullisilla vyöhykkeillä (Bengston, Fletcher \& Nelson, 2004, s. 276). Suomessa maankäyttö- ja rakennuslaki (132/1999) ohjaa käyttämään maankäyttösopimuksia, ja kehittämiskorvaus on mukana järjestelmässä lähinnä kuntien neuvotteluaseman helpottamiseksi (91 a § ja c §, 13.3.2003/222). Jotkut suomalaisen järjestelmän kriitikot ovatkin perustellusti tuoneet esille, että Yhdysvalloissa suositut selkeästi määritellyt kehittämismaksut olisivat läpinäkyvämpi ja vähemmän transaktiokustannuksia tuottava vaihtoehto maankäyttösopimuksille (chesire, 2012, s. 416-417; Loikkanen, 2013, s. 25-28). Kehittämismaksujen lisäksi Yhdysvalloissakin zoning-käytäntöihin toki liittyy koko joukko neuvottelupohjaisia mekanismeja (cullingworth \& caves, 20og, s. 112-123).

Kaiken kaikkiaan yhdysvaltalaisessa zoning-kritiikissä ei yleensä toivota zoning-järjestelmän lakkauttamista, vaan peräänkuulutetaan kiinteämpää yhteistyötä zoningin ja muiden ohjauskeinojen välillä. Erityisesti on toivottu parempaa jatkumoa yleispiirteisen suunnittelun ja zoningin välillä, eli sitä, että zoning-järjestykset seuraisivat yleispiirteisiä suunnitelmia ja myös että yleispiirteisiä suunnitelmia ylipäätään laadittaisiin. Huolenaiheet ovat pääpiirteissään samanlaisia kuin Suomessakin, missä on todettu muun muassa, että kaavahierarkia kääntyy toisinaan ylösalaisin, koska suunnittelun resurssit ovat kunnissa niukkoja, ja silloin on lyhyen tähtäimen näkökulmasta katsottuna helpompi tinkiä yleiskaavoituksesta kuin asemakaavoituksesta (Puustinen ym., 2013).

\section{Strateginen yleispiirteinen suunnittelu paikallistasolla}

Kuntien ja kaupunkien pitkän tähtäimen yleispiirteisen, pitkän aikavälin suunnittelun asema vaihtelee Yhdysvalloissa osavaltioittain. Jo 1920-luvulla luotu Standard State Zoning Enabling Act ohjasi kunnat laatimaan yleispiirteisen suunnitelman, joka osoittaisi kunnan zoning-käytännöille suuntaviivat, joskaan se ei määritellyt tarkemmin yleispiirteisen suunnitelman luonnetta (Elliot, 20o8). Yleispiirteisiä suunnitelmia kutsutaan yleensä nimellä "compre- 
hensive plan" ja toisinaan myös nimillä "general plan" tai "master plan" (Kelly, 2010, s. 47). Myöhemmin jotkin osavaltiot alkoivatkin vaatia lainsäädännössään, että kuntien on laadittava yleispiirteinen suunnitelma ja että niiden zoningmääräysten tulee olla suunnitelman mukaisia, kun taas toiset osavaltiot joko eivät ole vaatineet yleispiirteisiä suunnitelmia kunnilta, vaikkakin ovat nähneet niillä oikeudellisia vaikutuksia silloin kun niitä on laadittu, tai sitten ne eivät ole tunnustaneet lainkaan yleispiirteisten suunnitelmien oikeudellista merkitystä (sullivan, 2004). Yhdysvalloissa onkin paljon kuntia, joissa ei harjoiteta yleispiirteistä suunnittelua, vaan suunnittelu on typistetty zoning-käytäntöjen kautta tapahtuvaksi maanomistajien oikeuksien vakauttamiseksi ja vahvistamiseksi (Booth, 1996, s. 6). Silloinkin kun yleispiirteisten suunnitelmien oikeudellinen merkitys tunnistetaan, oikeusistuinten tulkinnat ovat vaihdelleet sen osalta, mikä lasketaan yleispiirteisen suunnitelman mukaisuudeksi ("in accordance with the plan") (sullivan, 2004). Etenkin suuremmissa kaupungeissa yleispiirteisestä maankäytön suunnittelusta on kuitenkin tullut yhä keskeisempi osa kaupungin strategista kehittämistä, ja myös kokonaisvaltaista suunnittelua kaupungeilta edellyttävien osavaltioiden määrä on kasvanut jatkuvasti (Kelly, 2010, s. 2).

Termissä "comprehensive plan" komprehensiivisuus eli kokonaisvaltaisuus viittaa yhtäältä suunnitelman maantieteelliseen kattavuuteen, joka käsittää tyypillisesti koko kunnan alueen. Yleispiirteiset suunnitelmat eivät kuitenkaan käsittele aluettaan yksityiskohtaisesti, koska ne ovat useamman vuosikymmenen aikatähtäimellä tehtäviä suunnitelmia, joissa on oltava strategista väljyyttä. Toisaalta kokonaisvaltaisuus viittaa siihen, että suunnitelmissa käsitellään maankäytön lisäksi kattavasti muitakin elinympäristöön vaikuttavia teemoja, kuten tärkeimpinä liikennettä, asumista, palveluverkkoa ja luonnonympäristöä, mutta nykyään mukana on usein myös esimerkiksi sosiaaliseen oikeudenmukaisuuteen, taloudelliseen kehitykseen sekä kulttuuriin liittyviä teemoja. (Miller, 2009; Kelly, 2010; Godschalk \& Rouse, 2015.) Tässä mielessä kokonaisvaltaiset suunnitelmat vertautuvat suomalaisiin kuntastrategioihin (ks. kuntalaki 410/2015, 37 §), joissa nivotaan yhteen eri hallintosektoreiden tavoitteet. Suomessa kuitenkin kuntastrategioiden yhteys maankäytön suunnitteluun jää usein verrattain heikoksi (ks. kuitenkin Granqvist ym., 2019; Granqvist ym., 2021).

Kokonaisvaltaisessa suunnittelussa eri teemoja tarkastellaan yleispiirteisen suunnitelman eri osioissa ("elements"), joissa myös eritellään näiden teemojen edellyttämiä toisistaan poikkeavia ohjaus- ja sääntelymekanismeja (Miller, 2009). Toisaalta nykyään myös tiedostetaan, että sekä aihepiirejä että niiden ohjausta on tarpeen tuoda linjakkaammin yhteen (Godschalk \& Rouse, 2015). Tämän takia suunnittelun lopputuloksena saattaa usein olla laaja kokoelma toisistaan eriäviä mutta myös toisiinsa kietoutuvia toteutusohjelmia. Esimerkkinä 
yleispiirteisen, strategisen suunnitelman rakenteesta mainittakoon vuoden 2020 keväällä lainvoiman saanut Minneapolis 2040 -suunnitelma, jonka moninaisista sosiaalisista, taloudellisesta, ekologisista ja kulttuurisista tavoitteista huolehditaan zoning-järjestyksen lisäksi peräti sadan eri sektoreita enemmän tai vähemmän yhdistävän toimintaohjelman avulla (ks. Minneapolis 2040 Policies). Silti zoning-järjestys on yleensä toteutuskeinoista keskeisin, ja etenkin Minneapolis 2040 -suunnitelman tapauksessa se myös hallitsi julkista keskustelua ja sai runsaasti julkisuutta valtakunnanlaajuisestikin, koska suunnitelmaan sisältyi Yhdysvalloissa ennenkuulumaton tavoite: yksinomaan omakotitaloille varatuista vyöhykkeistä luopuminen (ks. esim. Trickey, 2019).

Suomalaisittain kiinnostavaa on, että yhdysvaltalaisten yleispiirteisten suunnitelmien tavoitteiden toteuttamiselle laaditaan usein aikataulu ja tavoitteiden toteutumista seurataan etukäteen määriteltyihin mittareihin perustuen (Godschalk \& Rouse, 2015). Näin helpotetaan toteuttamista sekä mahdollistetaan korjausliikkeet siinä tapauksessa, ettei tavoitteita saavuteta (Miller, 20og). Korjausliikkeitä ei kuitenkaan yleensä tehdä jatkuvasti, vaan yleispiirteiset suunnitelmat ovat tyypillisesti säilyttäneet hankemaisen luonteensa, millä tarkoitan sitä, että niitä päivitetään suhteellisen harvoin, esimerkiksi vuosikymmenittäin. Tämä liittynee Yhdysvalloissa tyypilliseen yleispiirteisen suunnittelun voimakkaaseen poliittisuuden korostamiseen, sillä suuret, harvemmin toistuvat suunnitteluhankkeet saavat tyypillisesti paljon julkisuutta ja aktivoivat osallisia keskustelemaan suunnittelun päämääristä (ks. esim. Kelly, 2010).

\section{Suomalainen suunnittelujärjestelmä}

ja suunnittelun strategisuus

Toisin kuin Yhdysvalloissa, Suomessa, Pohjoismaissa ja Manner-Euroopassa suunnittelujärjestelmät rakentuvat tyypillisesti hierarkkisesti tarkentuvan kaavaohjauksen varaan ja ylikunnallinen taso on järjestelmissä vahvemmin esillä kuin yhdysvaltalaisissa järjestelmissä, jolloin strategisen suunnittelun ja toteuttavan tason erottelua on vaikea tehdä. Eurooppalaista strategista spatiaalista suunnittelua koskevassa keskustelussa on toisinaan jopa esitetty, etteivät hierarkkisesti tarkentuvat ja kaavoihin perustuvat järjestelmät periaatteessakaan mahdollista strategista suunnitteluotetta. On väitetty, että kaavat keskittyvät fyysiseen ympäristöön eivätkä toimintaan. Ne eivät siksi edistä parhaalla mahdollisella tavalla hallinnonalojen välistä yhteistyötä, mitä tarvittaisiin esimerkiksi kaupunkien tai kaupunkiseutujen sosiaalisen ja taloudellisen kehityksen hallinnassa. (Albrechts, 2004, s. 745-747.) Lisäksi kaavojen maantieteellisiä rajauksia on pidetty jäykkinä tilanteessa, jossa todellisen maailman suunnitteluongelmat vaatisivat joustavaa skaalautuvuutta (Healey ym., 1997; Albrechts 2004, s. 749). 
Tässä tilanteessa strateginen suunnittelu on näyttäytynyt monille eurooppalaisille suunnitteluteoreetikoille lakiin perustuvien maankäytön suunnittelua ohjaavien järjestelmien ulkopuolisena vaihtoehtona, jossa kehitystä ohjataan kaavojen sijaan väljempien "strategisten kehysten" avulla ja päätöksenteossa nojataan virallisten päätöstentekoelinten sijaan laajempiin, epämuodollisiin hallintaverkostoihin. (Albrechts, 2004; ks. myös Albrechts \& Balducci, 2013; ks. myös Healey, 2007.) Tältä osin eurooppalainen strategista suunnittelua koskeva keskustelu poikkeaa merkittävästi yhdysvaltalaisesta keskustelusta, jossa kaikki yleispiirteinen suunnittelu - ja usein nimenomaan lakiin perustuva suunnittelu - ymmärretään tyypillisesti luonteeltaan strategisena suunnitteluna (ks. esim. Bryson \& schively Slotterback, 2017).

\section{Yleispiirteisen suunnittelun strategisuus Suomessa}

Suomessa strateginen suunnittelu on osittain rakentunut lakisääteisen suunnittelun rinnalle. Ympäristöministeriön STRASI-hankkeessa (Strategisen suunnittelun sisältö ja muodot alueidenkäytössä) tunnistettiin alueidenkäytön strategisten valintojen kannalta merkityksellisiksi suunnitteluvälineiksi paitsi maankäyttö- ja rakennuslain (132/1999) mukaiset yleis- ja maakuntakaavat sekä kuntien yhteiset yleiskaavat, myös esimerkiksi seutu- ja kuntastrategiat, rakennemallit ja kehityskuvat, maakuntasuunnitelmat ja -ohjelmat sekä maapoliittiset ohjelmat (Laitio \& Maijala, 2010, s. 27-28). Maankäyttö- ja rakennuslain ulkopuolisia strategisen suunnittelun välineitä on arvosteltu tutkimuskirjallisuudessa, koska moninaisten strategisten suunnitelmien ja prosessien viidakossa kansalaisten - ja toisinaan jopa poliittisten päättäjien - on hankalaa hahmottaa, missä ja milloin strategiset valinnat tehdään, ja koska osallisille ei ole taattu epävirallisissa suunnitteluprosesseissa samanlaisia osallistumismahdollisuuksia suunnitteluun kuin lakiin perustuvissa kaavaprosesseissa (Mäntysalo \& Jarenko, 2012; Mäntysalo, Kangasoja \& Kanninen, 2015; Bäcklund ym., 2018). Muun muassa näistä syistä monet suomalaiset tutkijat ovat korostaneet, ettei strategisuutta tule nähdä irrallaan lakisääteisistä suunnittelun välineistä (Mäntysalo, Kangasoja \& Kanninen, 2015; Mäntysalo ym., 2019). Tämä puoltaa suunnittelujärjestelmän kehittämistä suunnittelun strategisuutta painottavaan suuntaan.

Suomessa yleiskaavat ovat tilastojen perusteella useimmiten perinteisiä aluevarauskaavoja ja usein myös maantieteellisesti vain osan kunnan alueesta kattavia kaavoja eivätkä näiltä osin ilmennä strategisuutta (Ympäristöministeriö, 2014, s. 31). Viime aikoina kuitenkin useat suuret tai kasvavat suomalaiset kaupungit ovat pyrkineet osoittamaan, että myös maankäyttö- ja rakennuslain mukaisiin yleiskaavoihin voi sisällyttää strategisen suunnittelun piirteitä (Koivu ym. 2013; Hastio ym., 2018). Esimerkiksi Lahdessa on haettu toimintasuuntautuneempaa otetta "rullaavan", 
valtuustokausittain syklisesti päivittyvän koko kaupungin kattavan yleiskaavan kautta (ks. esim. Koivu ym., 2013; Hastio ym., 2018; Mäntysalo ym., 2019). Voimavarojen suuntaaminen yleiskaavoitukseen ei ole tällöin niin haastavaa kuin harvoin toistuvissa suurissa yleiskaavahankkeissa. Malli tukeekin strategisuutta varmistaessaan, että yleispiirteistä suunnittelua ylipäätään tehdään kattavasti ja ajantasaisesti ja että päätöksiä saadaan aikaan ristiriitaisessakin tilanteessa, kun näkyvillä on jo seuraavia tilaisuuksia päätösten tarkistamiseen. Sen heikkoutena saattaa puolestaan olla, ettei se tee tärkeitä strategisia valintoja riittävän näkyviksi osallisille. Suomessa ei kuitenkaan ole ollut tavallista, että suunnittelun suuntaviivoja olisi tarpeen muuttaa perinpohjaisesti ja sitouttaa toimijoita uusiin strategisiin valintoihin harvoin toistuvissa korkean profiilin yleiskaavahankkeissa, toisin kuin Yhdysvalloissa. Siellä monissa tähän asti esikaupunkimaisen elämäntavan ihanteen varaan rakentuneissa suurkaupungeissa urbanististen ihanteiden sisällyttäminen yleispiirteisen suunnittelun tavoitteistoon on ollut merkittävä strateginen suunnanmuutos, joka on vaatinut paljon julkista keskustelua. Suomessakin on silti toteutettu päämäärävalintoja korostavia suuria, hankemaisia yleiskaavoja, kuten Helsingin tuoreehko "Kaupunkikaava", jossa strategisuus on liittynyt yleispiirteiseen esitystapaan ja määräysten joustavuuteen mutta samalla myös ohjaavuuteen etenkin raideliikenneyhteyksien ja rakentamisen mitoituksen suhteen (Hastio ym., 2018, s. 46-50).

Vaikka strateginen yleispiirteinen kuntatason suunnittelu on mahdollista nykyisenkin lain puitteissa, parhaillaan käynnissä olevan maankäyttö- ja rakennuslain kokonaisuudistuksen taustakeskusteluissa lukuisat tahot sekä yksityisellä että julkisella sektorilla ovat toivoneet, että uudistuva lainsäädäntö ohjaisi yleispiirteisempää suunnittelua strategisempaan suuntaan ja erottaisi sen tehtävät selkeämmin asemakaavoituksen tehtävistä (ks. esim. Hurmeranta, 2013; Ympäristöministeriö, 2014, s. 34). Yksityisen sektorin edustajille strategisuus on merkinnyt paitsi suunnitteluprosessien tehokasta etenemistä varsinkin kasvavilla kaupunkiseuduilla, myös lopputulosten ennustettavuutta (ks. esim. Hurmeranta, 2013). Ennustettavuuden pitäisi periaatteessa olla mannereurooppalaisten, asteittain tarkentuviin kaavoihin perustuvien järjestelmien vahvuus verrattuna brittiläisiin tai yhdysvaltaisiin järjestelmiin (Booth, 1996). Kriitikoiden mukaan omassa järjestelmässämme ennustettavuus ei kuitenkaan toteudu parhaalla mahdollisella tavalla, koska suomalaisista asteittain tarkentuvista kaavoista puuttuu usein linjakkuutta - toisinaan koska yleiskaavassa ratkotaan asemakaavatason kysymyksiä, jotka avataan uudestaan asemakaavoituksen yhteydessä, ja toisinaan koska lainvoimaisen yleiskaavan puuttuessa asemakaavoituksen yhteydessä joudutaan tekemään yleisluontoista suunnittelu- ja selvitystyötä (Hurmeranta, 2013). 
Strategisen ja toteuttavan suunnittelun välisen tehtävänjaon selkiyttäminen oli keskiössä ympäristöministeriön tilaamassa, maankäyttö- ja rakennuslain uudistuksen tueksi tarkoitetussa professori Ari Ekroosin johdolla toimineen viiden selvityshenkilön raportissa (Ekroos ym., 2018). Selvitysryhmä ehdotti nykyisen yleiskaavoituksen tilalle kunnan maankäytön yleissuunnitelmaa, jonka laatimistarpeesta säädettäisiin yksityiskohtaisemmin kuin nykyisen yleiskaavan tapauksessa, ja asemakaavoituksen tilalle suppeamman alueen maankäytön kehittämissuunnitelmaa, johon sisältyisi myös nykyisin rakennuslupaharkinnan piiriin kuuluvia kysymyksiä ja jonka kohdalla osa päätöksistä voisi olla viranomaispäätöksiä (Ekroos ym., 2018, s. 33-45). Ryhmä tosin käyttää termiä "strateginen suunnittelu" vain oikeusvaikutuksettomasta yleispiirteisestä suunnittelusta, jota voitaisiin ryhmän näkemyksen mukaan toteuttaa kunnallisella ja ylikunnallisella tasolla. Oikeusvaikutteista yleispiirteistä suunnittelua puolestaan toteutettaisiin vain kuntatasolla, ja kuntatason yleispiirteiset suunnitelmat voisivat tarvittaessa ohjata suoraan rakentamista. (Ekroos ym., 2018, s. 36.) Jos "strategisuudella" viitataan tehokkaaseen ohjaavuuteen, silloin suomalaisen järjestelmän tapauksessa ei oikeusvaikutteisuutta ehkä kannattaisi rajata pois strategisen suunnittelun piiristä ainakaan niiltä osin, kun oikeusvaikutuksilla tarkoitetaan suunnitelmien sitovuutta alempien kaavatasojen päätöksenteossa. Vaikka oikeusvaikutteisuuden merkitystä ei ole korostettu kansainvälisessä strategisen suunnittelun kirjallisuudessa, on muistettava, että omassa järjestelmässämme - toisin kuin kansainvälisen suunnitteluteoreettisen keskustelun taustalla usein vaikuttavassa tapaoikeuden perinteessä - oikeusvaikutukset eivät yleensä ilmaannu oikeusistuimien päätöksiin, ellei lainsäätäjä ole niistä säätänyt etukäteen.

Selvityshenkilöiden raportin (Ekroos ym., 2018) ajatus kunnan maankäytön yleissuunnitelmasta pohjusti strategista "yhden kuntakaavan" mallia, jota hahmoteltiin ympäristöministeriön keskustelupaperissa maankäyttö- ja rakennuslain uudistamisen suuntaviivoiksi keväällä 2018 (Ympäristöministeriö, 2018). Kuntakaava olisi ollut skaalautuva, ja se olisi sisältänyt yleisiä linjauksia koskevan osan eli kehittämisperiaatteet ja toteuttamisosan. Kehittämisperiaatteiden ja toteuttamisosan eriyttäminen toisistaan olisi selkiyttänyt järjestelmää kuntatasolla ja oletettavasti vienyt rakennetta strategiseen suuntaan siinä merkityksessä, jossa strategisuus ymmärretään yhdysvaltalaiselle suunnittelulle tyypillisessä erottelussa yleispiirteisen ja toteuttavan suunnittelun välillä. Syksyllä 2019 kommentoitavaksi annetuissa uuden lain pykäläluonnoksissa (Alueidenkäytön suunnittelujärjestelmä, alustavia pykäläluonnoksia 11.10.2019) tämän tyyppinen jako näkyy kehittämisperiaatteiden ja kuntakaavamääräysten välisenä erotteluna. Muutoin kuitenkin strategisen ja toteuttavan tason erottelu jää pykäläluonnoksissa 
keskeneräiseksi, ja niissä on tyydytty monelta osin vain yhdistämään yleiskaavan ja asemakaavan ominaisuudet (Alueidenkäytön suunnittelujäriestelmä, alustavia pykäaläuonnoksia 11.10.2019; ks. myös Kokousmuistio, MRL-uudistus / työryhmän 21. kokous). Tämä on omiaan enemmänkin hämärtämään strategisen ja toteuttavan suunnittelun tason erottelua kuin selkiyttämään sitä (vrt. Nykänen, 2021).

Toisaalta suurilla kaupunkiseuduilla strategisuuteen liittyvä työnjako olisi kuitenkin sisältynyt yhden kuntakaavan malliin siinäkin tapauksessa, että kuntakaava itsessään ei olisi tätä jakoa toteuttanut, sillä kuntakaavan yläpuolelle kaavahierarkiaan oli suunniteltu kaupunkiseutukaava, jonka tehtävänä olisi ollut ohjata kuntien kaavoitusta (ks. Kokousmuistio, MRL-uudistus / työryhmän 17. kokous). Tämä olisikin ollut tervetullut uudistus, sillä kuntien laaja valta maankäyttöasioissa on mahdollistanut monella kasvavalla kaupunkiseudulla kuntien kilpailun niin kutsutuista hyvistä veronmaksajista. Tämä ei ole tapahtunut pelkästään väljien omakotitaloalueiden kaavoittamisen keinoin, vaan myös siten, että omakotirakentamista ei ole ohjattu kaavoilla lainkaan, jolloin se on toteutunut hajarakentamisena (ks. esim. Hytönen ym, 2016; Heinilä, 2017). Tällaista kehitystä ei ole pidetty kestävänä eikä kaupunkiseutujen kokonaisetua palvelevana.

Yhden kuntakaavan mallia simuloitiin syksyllä 2019 ympäristöministeriön Kuntaliitolta tilaamassa kehittämishankkeessa, jossa olivat mukana Jyväskylä, Lappeenranta, Hyvinkää, Iisalmi ja Ilmajoki. Yksikään Suomen kuudesta suurimmasta kaupungista ei ollut mukana simulaatiossa, vaikka etenkin yksityisen sektorin mielenkiinto on kohdistunut suunnittelun kehittämiseen voimakkaimmin kasvavilla kaupunkiseuduilla. Mallin ongelmana pidettiin simulaation perusteella sitä, että kuntakaavasta saattaa tulla yksittäisten hankkeiden tarpeisin reagoiva "ameeba", joka rapauttaisi suunnittelun strategisuutta pikemminkin kuin vahvistaisi sitä (Kuntaliitto, 202o, s. 45). Kokeiluun osallistuneissa kunnissa ei pääsääntöisesti kyetty hahmottamaan riittävän hyvin, mitä kehittämisperiaatteet olisivat sisältäneet ja kuinka tehokkaasti ne olisivat ohjanneet kehitystä, kun taas perinteisten aluevarausten tulkinta ja ohjausvaikutus avautuivat kuntien edustajille huomattavasti helpommin (Kuntaliitto, 2020, s. 46).

Vaikka pikainen simulaatio tuskin olisi missään tapauksessa voinut tuottaa kirkastunutta ymmärrystä keskeneräisen mallin toiminnasta (vrt. Lehtovuori \& Rajaniemi, 2021), lain valmistelussa ei ryhdytty selkiyttämään ja tarkentamaan kehittämisperiaatteiden ja niihin sisältyvien ohjausmekanismien luonnetta. Sen sijaan palattiin takaisin perinteiseen yleiskaavan ja asemakaavan malliin (Kokousmuistio, MRL-uudistus / työryhmän 17. kokous).

Pian tämän jälkeen myös kaupunkiseututason kaavasta luovuttiin, jotta kaavatasojen määrä ei kasvaisi. Kaupunkiseututasoisen kaavan tilalle tuotiin oikeusvaikutukseton "kaupunkiseutusuunnitelma" (Kokousmuistio, MRL-uudistus/työryhmän 
21. kokous.) Siinä missä kunnat olivat huolestuneita yleispiirteisen suunnittelun ohjaavuudesta siinäkin tapauksessa, että kehittämisperiaatteet olisivat olleet muodollisesti velvoittavia (Kuntaliitto, 2020), kaupunkiseututasoisen oikeusvaikutuksettoman suunnittelun ohjaavuudesta ei tuotu esiin vastaavaa huolestuneisuutta lain valmisteluprosessissa - näin siitäkin huolimatta, että Suomen ympäristökeskuksen laatima raportti kaavailtujen eri vaihtoehtojen vaikutuksista korostaa, että oikeusvaikutuksettomana kaupunkiseutusuunnitelma voi "jäädä heikoksi ohjausvälineeksi, joka ei pysty vastaamaan riittävän voimallisesti kaupunkiseutujen haasteisiin" (Saarela ym., 2019, s. 18).

Ohjaavuus ei tietenkään liity pelkästään kaupunkiseutusuunnitelmien oikeusvaikutuksiin, vaan myös niiden sisältöihin. Jotta kuntien osaoptimointi ei hallitsisi sisältöjen muotoilua ja jättäisi suunnitteluun satunnaisesti täyttyviä "strategisia tavoitetyhjiöitä" (Hytönen \& Ahlqvist, 2019), vaan suunnittelussa päästäisiin hahmottamaan ylikunnallisten yhteisten ja yleisten etujen mukaista yhdyskuntarakenteen ohjausta, ylikunnallisen suunnittelun institutionaalisen aseman vahvistaminen saattaisi olla tarkoituksenmukaista muutoinkin kuin suunnittelun oikeusvaikutteisuuden kautta. Yhdysvalloissa paikallinen taso on perinteisesti ollut institutionaalisesti vahva kuten meilläkin, mutta Oregonin Portlandin ja Minnesotan Minneapolis- Saint Paulin esimerkit osoittavat, että tällaisessakin toimintaympäristössä on mahdollista ajan myötä vakiinnuttaa institutionaalinen asema vahvasti ohjaavalle seutusuunnittelulle (Taylor, 2019). Silti erityisesti Minneapolisin ja Saint Paulin metropolialueen ongelmana on ollut, että kaupunkiseututasoisen demokraattisesti valitun päätöksentekoelimen puuttuessa legitimiteettiä on täytynyt hakea lähinnä suunnittelun lopputulosten kautta. Kestäviä lopputuloksia taas on vaikeaa saavuttaa, jollei suunnittelua koeta lähtökohtaisesti legitiimiksi. Lisäksi silloinkin, kun suunnittelulle on saatu oikeutusta esimerkiksi kansalaisten osallistamisen kautta, kaupunkiseututasoisen suunnittelun tuottama "yhteinen hyvä" on syntynyt kuntien näkökulmasta hitaasti verrattuna osaoptimoivan kuntasuunnittelun tuottamiin pikavoittoihin. (Taylor, 2019.) Kaupunkiseututasoinen suunnittelu on kestävän kehityksen kannalta avainasemassa (Wheeler, 20oo; Janssen-Jansen \& Hutton, 2011; Ravetz, 2013), mutta sen institutionalisoitumista jarruttavat usein siis rakenteelliset, kehämäiset haasteet. Tämä olisi hyvä muistaa myös omassa toimintaympäristössämme. Tällä hetkellä meillä tunnutaan luottavan siihen, että vahvaa järjestelmätason tukea kaupunkiseutusuunnittelun institutionalisoitumiselle ei tarvita, vaikka kaupunkiseutusuunnittelun vahvistamisen tarpeellisuus tunnistetaan. 
Yksityiskohtainen suunnittelu ja asemakaavoituksen tulevaisuus

Vaikka yleispiirteisenkin suunnittelun uudistaminen järjestelmätasolla näyttää tällä hetkellä kaatuvan näkemyseroihin, erimielisyydet ovat hallinneet myös yksityiskohtaisen suunnittelun ja asemakaavoituksen tulevaisuutta koskevaa keskustelua. Asemakaavoitusta on kritisoitu sille annettujen tehtävien runsaudesta ja asemakaavoja niiden liiallisesta tarkkuudesta, jonka johdosta suunnittelu hidastuu ja asemakaavoista poiketaan paljon (Hurmeranta, 2013; Kilpailuja kuluttajavirasto, 2013, s. 22-24; Loikkanen, 2013, s. 42-43; ks. myös Mattila, 2017, 2018b, s. 105-106). SuOMeSSa poikkeaminen siis johtuu eri syystä kuin Yhdysvalloissa, missä poikkeamisten taustalla on tyypillisesti yksityiskohtaisuuden puute vyöhykkeiden sääntelyssä. Asemakaavoituksen tulee zoningin tapaan vakiinnuttaa maanomistajien oikeudet ja parantaa ennustettavuutta sekä rakentajien että muiden toimijoiden näkökulmasta, mutta lisäksi asemakaava on ollut perinteisesti tärkeä kaupunkikuvan sääntelyn - tai oikeastaan suunnittelun - väline ainakin suurissa kaupungeissa, joissa asemakaavoitus on lähes poikkeuksetta arkkitehtien tehtäväkenttää. Lisäksi asemakaavalla pyritään takaamaan lukuisia muita ympäristön viihtyisyyteen, terveellisyyteen ja turvallisuuteen liittyviä laatutekijöitä. Myös uusia, esimerkiksi ympäristön yhteisöllisyyttä tukevia tehtäviä on ehdotettu lisättäväksi asemakaavatasoisen suunnittelun tehtäväkenttään (Leino \& Maununaho, 2020).

Yhdysvaltalainen zoning on pelkistettyydessään yksityiskohtaisen suunnittelun välineenä toista maata kuin suomalainen asemakaavoitus. Vaikka jotkut kriittiset suunnittelututkijat kritisoivat zoningia sen kapeakatseisuudesta, zoningin puolustukseksi voi sanoa, että se on avoimesti juuri sitä mitä se on - se määrittää maanomistajien ja rakentajien oikeudet sekä vakauttaa taloudellista toimintaympäristöä. Suomalaista asemakaavoitusta on kritisoitu siitä, että toimittaessaan useita tehtäviä yhtäaikaisesti - maankäyttö- ja rakennuslain mukaan lähinnä yleviä, ympäristön laadun turvaamiseen liittyviä tehtäviä eikä niinkään omaisuuksien arvoon liittyviä tehtäviä - asemakaavoitus altistuu patologisoitumiselle (Nyman \& Mäntysalo, 2014). Tämä tarkoittaa sitä, että asemakaavoitus saatetaan esittää ensisijaisesti ympäristöarvoja ja parempaa tulevaisuuden elinympäristöä palvelevana käytäntönä niin yleisölle kuin suunnittelijoiden omalle itseymmärrykselle, mutta usein kaavojen taustalla on kuitenkin yksityisen sektorin omaisuuden arvoon liittyvät intressit (Nyman \& Mäntysalo, 2014). Yksityisomaisuuden arvon turvaamisessa ei välttämättä ole mitään väärää; päinvastoin, usein on yleisen edun mukaista suojata markkinatoimijoita tarpeettomilta omaisuuden arvon notkahduksilta. Ongelmallista kuitenkin on, jos suunnittelujärjestelmä ei tunnista ja tunnusta tätä taloudellista tehtävää. Tämä ei lisää luottamusta järjestelmään, etenkin kun kriittisten tutkijoiden 
mukaan suomalainen suunnittelu on muuttunut tai muuttumassa yhä markkinaehtoisemmaksi (ks. esim. Mäntysalo \& Saglie, 2010; Mattila, 2018a; Hytönen \& Ahlqvist, 2019). Vaikka Yhdysvalloissa yksityisen sektorin vaikutusvalta on juurtunut kulttuurisesti syvemmälle kuin meillä, järjestelmätasolla amerikkalainen zoning on vähemmän altista tällaisille patologisoitumistaipumuksille.

On myös muistettava, ettei zoning edusta koko totuutta strategisten suunnitelmien toimeenpanosta Yhdysvalloissa, vaan zoningin lisäksi yleispiirteisiä suunnitelmia toteutetaan esimerkiksi kaupunkikuvan ja ympäristön sosiaalista laatua koskevien tavoitteiden osalta sekä yksittäisten toimialojen että useita toimialoja yhdistävien toimintapolitiikkojen avulla. Silti tasapuolisuuden nimissä on mainittava, että toki Yhdysvalloissakin on keskusteltu esimerkiksi juuri kaupunkikuvallisten tekijöiden nykyistä kiinteämmästä roolista zoningissa. Erityisesti uusurbanistista suuntausta edustavat arkkitehdit ovat puhuneet muotoperustaisen kaavoituksen (form-based zoning) puolesta. Heidän tavoitteenaan on ollut kyseenalaistaa kaupungin elävyydelle haitallinen toimintojen erottelu ja korostaa sen sijaan suunnittelun design-ulottuvuuden merkitystä toimintojen onnistuneen synergian luomisessa (Elliot, 2008, s. 26-34). Lisäksi muotoperustaisen sääntelyn on ajateltu tuottavan oikein visualisoituna osallisille nykyistä tarkemman käsityksen siitä, millaista lähiympäristöä sääntely synnyttää (Hirt, 2014, s. 48; Moga, 2017). Muotoperustaista kaavoitusta on kuitenkin toistaiseksi harjoitettu Yhdysvalloissa lähinnä vain yksittäisten uusien aluekokonaisuuksien suunnittelussa (Hirt, 2014, s. 49), ja sitä on kritisoitu - aivan kuten Suomessa on kritisoitu asemakaavoitusta - sen tuottaman joustamattoman ja yksityiskohtaisen sääntelyn takia (Elliot, 2008, s. 33-34).

Suomalaisen asemakaavoituksen uudistustarpeista ei ole toistaiseksi päästy juurikaan keskustelemaan lainsäädännön uudistuksen yhteydessä. Keskustelu on lukkiutunut kunnan ja maanomistajien väliseen vallanjakoon asemakaavan valmistelussa (MRL-uudistuksen tilannekatsaus 28.9.2020). Vaikka erilaisia tavoitteita yhdistelevällä suomalaisella asemakaavalla on omat vahvuutensa erityisesti kaupunkikuvan laadun varmistamisessa, olisi hyödyllistä ainakin tutkia yksityiskohtaisen suunnittelun työvälinevalikon monipuolistamista ulkomaisten esimerkkien valossa. Keinovalikoiman monipuolistaminen selkiyttäisi yksittäisten välineiden tehtäviä sekä mahdollistaisi uudenlaisia lähestymistapoja välineiden käyttöön liittyviin valta- ja vastuusuhteisiin.

\section{Lopuksi}

Yhdysvaltalaisten suunnittelujärjestelmien keskeinen suunnittelun strategisuutta vahvistava piirre on se, että strategisten tavoitevalintoja tuottavan ja tavoitteita toteuttavan suunnittelun työvälineet ja prosessit on erotettu 
selkeästi toisistaan. Tämä lähtökohta tekee strategisten valintojen paikat näkyväksi eri toimijaryhmille. Se myös mahdollistaa analyyttisen otteen erilaisten tavoitteiden jäsentelyssä ja edistää innovatiivisten, tavoitteisiin vastaavien ohjauskeinojen valinnassa. Tällöin myös osalliset voivat paremmin seurata, ollaanko valittuja tavoitteita toteuttamassa ja miten niitä toteutetaan. Kun toteutusvälineisiin sisällytetään zoning-järjestysten ohella monipuolisesti muitakin ohjausvalineitä, kaupunkilaiset ja toimijat hallinnon muilla sektoreilla kokevat maankäytön suunnittelun helpommin lähestyttäväksi asiaksi. Tämä puolestaan on omiaan nostamaan maankäytön suunnittelun kaupunkien strategisen kehittämisen ydinasiaksi.

Suomessa sekä strategisen että toteuttavan tason suunnittelua tehtäneen lakiuudistuksen jälkeenkin kunnissa virallisesti pääosin kaavoilla. Jos vain sääntelyn tarkkuustaso vaihtelee, mutta väline pysyy samana, työnjaon selkiyttäminen kaavatasojen välillä ei ole helppoa. Koska kaava ei taivu kaikkeen, kaavojen ohella tullaan luultavasti tarvitsemaan yhä kasvava joukko epämuodollisia suunnitteluvälineitä. Tämä ei näyttäydy suunnittelujärjestelmän selkiytymisenä, mikä oli yksi uudistuksen alkuperäisistä tavoitteista.

Suunnitteluprosessien sujuvoittaminen on kuitenkin edelleen uudistuksen tavoitelistalla, ja sitä ollaan tällä hetkellä edistämässä mahdollistamalla asemakaavan ja yleiskaavan yhtäaikaiset muutokset (MRL-uudistuksen tilannekatsaus 28.9.2020). Vaikka prosessien vauhdittaminen on kannatettavaa, tämä malli saattaa altistaa strategiset valinnat yksittäisiin hankkeisiin reagoivalle joustolle. Joustavuuttakin toki tarvitaan pitkän tähtäimen suunnittelussa, jonka täytyy voida reagoida toimintaympäristön yllättäviin muutoksiin. Silti voi kysyä, onko joustavuuden edistäminen jo ohittanut tavoitelistalla ohjaavuuden parantamisen yleispiirteisessä suunnittelussa, kun taas asemakaava on jäämässä joustamattomaksi ja ensisijaisesti kaupunkiarkkitehtonisiin päämääriin keskittyväksi osaksi suunnittelujärjestelmää, mikä tuntuisi nurinkuriselta ajatellen uudistuksen alkuperäisiä tavoitteita ja sille asetettuja odotuksia.

Huoli ohjaavuuden kärsimisestä joustavuuden kustannuksella herää erityisesti, koska paikallisen yleispiirteisen suunnittelun joustavoittamisen lisäksi ylikunnallisen tason suunnittelu näyttää viimeisimpien tietojen valossa menettävän oikeudellisen sitovuutensa ja sallivan siten yhä enemmän paikallistason joustoa. Näin näyttäisi käyvän paitsi suunnitellulla uudella kaupunkiseutusuunnittelun tasolla myös osittain maakuntakaavan tasolla (MRL-uudistuksen tilannekatsaus 28.9.2020). Yhdysvaltalaiset ja monet muutkin ulkomaiset esimerkit ovat osoittaneet, että ylikunnallisen suunnittelun institutionalisoiminen ja sen ohjaavuuden vahvistaminen on hidasta ja se kohtaa rakenteellisia esteitä toimintaympäristöissä, joissa paikallistaso on institutionaalisesti vahva. Silti 
kestävän kehityksen näkökulmasta juuri ylikunnallisen suunnittelun taso vaatisi huomiota etenkin kasvavilla kaupunkiseuduilla. Tästä syystä voi kysyä, kannattaisiko strategisuuden nimissä sittenkin jatkaa ylikunnallisen suunnittelun institutionaalista vahvistamista käynnissä olevan lakiuudistuksen yhteydessä.

Strategisuudesta on tullut suunnittelun ominaisuus, jota kaikki haluavat edistää suunnittelujärjestelmäämme uudistettaessa, mutta jonka merkityksestä ei näytä vallitsevan yksimielisyyttä. Yhdysvaltojen esimerkki osoittaa, että strategisuuden ei tarvitse jäädä tyhjäksi käsitteeksi, vaan sillä voi olla myös verrattain selkeästi määritelty sisältö, joka heijastuu järjestelmätasolle ja ohjaa käytännön suunnittelua. Tällä en kuitenkaan tarkoita, että juuri yhdysvaltalainen strategisen suunnittelun ymmärrys olisi meille oikea tapa toteuttaa strategisuutta - päinvastoin, esimerkiksi paikallistasoa painottaessaan yhdysvaltalainen malli ei ole meille ihanteellinen varsinkaan kasvavien kaupunkiseutujen suunnittelun näkökulmasta. Yhdysvaltalainen tehokkuutta painottava ymmärrys on muutoinkin kehittynyt ympäristössä, jossa kaupunkien suuriin ongelmiin on täytynyt päästä käsiksi nopeasti ja jossa julkisen sektorin suunnittelun institutionaalinen asema on heikompi kuin meillä. Euroopassa toimintaympäristö on perinteisesti ollut toisenlainen. Perimmäinen kysymys onkin, haluammeko ylipäätään edistää strategisuutta vai pitäisikö suunnittelulta toivotuista ominaisuuksista oikeastaan keskustella joillain muilla käsitteillä. Tämä on kysymys, jonka olen kuullut yhdysvaltalaisten kollegojen esittävän meille eurooppalaisille suunnittelijoille ja suunnittelututkijoille aina toisinaan, kun heille on ollut haasteellista ymmärtää eurooppalaista puhetta strategisuudesta. Jos strategisuudelle kuitenkin todetaan olevan tilausta järjestelmässämme, strategisuuden luonteesta olisi keskusteltava yksityiskohtaisesti, esimerkiksi erilaisten käsitettä konkretisoivien esimerkkien kautta muualta maailmasta. Jos näkemykset strategisuudesta jäävät kovin ristiriitaisiksi, uhkana näyttää olevan, että tuleva maankäytön suunnittelun järjestelmämme ei vastaa kenenkään käsitystä strategisuudesta.

LÄHTEET

Albrechts, L. (2004). Strategic (spatial) planning reexamined. Environment and Planning B: Planning and Design, 31(5), 743-758. DOI: 10.1068/b3065.

Albrechts, L. \& Balducci, A. (2013). Practicing strategic planning: In search of critical features to explain the strategic character of plans. disP - The Planning Review, 49(3), 16-27. DOI: 10.1080/02513625.2013.859001

Albrechts, L., Healey, P. \& Kunzmann, K. R. (2003). Strategic spatial planning and regional governance in Europe. Journal of the American Planning Association, 69(2), 113-129. DOI: 10.1080/01944360308976301

Alterman, R. (2011). Regulatory takings and the role of comparative research. Teoksessa R. Alterman (toim.), Takings international: a cross-national perspective. Chicago: American Bar Association.

Alueidenkäytön suunnittelujärjestelmä, alustavia pykäläluonnoksia 11.10.2019. Ympäristöministeriö. https://mrluudistus.fi/wp-content/uploads/2019/10/Alueidenk\%C3\%A4yt\%C3\%B6n-suunnitteluj\%C3 \%A4rjestelm\%C3\%A4n-alustavat-pyk\%C3\%A41\%C3\%A4luonnokset_111019.pdf (viitattu 31.5.2021) 
American Planning Association. (2020). Standard Zoning Enabling Act and Standard City Planning Enabling Act. https://www.planning.org/growingsmart/enablingacts/ (viitattu 25.10.2020).

Bengston, D. N., Fletcher, J. O. \& Nelson K. C. (2004). Public polices for managing urban growth and protecting open space: Policy instruments and lessons learned in the United States. Landscape and Urban Planning, 69(2-3), 271-286. DOI: 10.1016/j.landurbplan.2003.08.007

Booth, P. (1996). Controlling development: Certainty and discretion in Europe, the USA and Hong Kong. London: UCL Press.

Booth, P. (2007). The control of discretion: Planning and the common-law tradition. Planning Theory, 6(2), 127-145. DOI: $10.1177 / 1473095207077585$

Bryson, J. M. (1988). A strategic planning process for public and non-profit organizations. Long Range Planning, 21(1), 73-81. DOI: 10.1016/0024-6301(88)90061-1

Bryson, J. M. (2001). Strategic planning. Teoksessa N. J. Smelser \& P. B. Baltes (toim.), International Encyclopedia of the Social and Behavioral Sciences. Oxford: Pergamon.

Bryson, J. M. (2003). Strategic planning and management. Teoksessa P. G. Peters \& J. E. Pierre (toim.) Handbook of Public Administration. Thousand Oaks, CA: Sage Publications.

Bryson, J. M., Crosby, B. C. \& Stone, M. (2006). The design and implementation of cross-sector collaborations: Propositions from the literature. Public Administration Review, 66, 44-55.

Bryson, J. M. \& Schively Slotterback, C. (2017). Strategic planning in the USA. Teoksessa L. Albrechts, A. Balducci \& J. Hillier (toim.), Situated practices of strategic planning. An international perspective. New York, NY: Routledge.

Bäcklund, P., Häikiö, L., Leino, H. \& Kanninen, V. (2018). Bypassing publicity for getting things done: Between informal and formal planning practices in Finland. Planning Practice \& Research, 33(3), 309-325. DOI: 10.1080/02697459.2017.1378978

Chesire, P. (2012). Kaupunkialueiden maamarkkinoiden säätelypolitiikasta ja sen epäonnistumisista. Teoksessa: Loikkanen, H., Laakso, S. ja Susiluoto, I. (toim.) Metropolialueen talous. Näkökulmia kaupunkitalouden ajankohtaisiin aiheisiin. Helsinki: Helsingin kaupungin tietokeskus.

Cullingworth, B. \& Caves, R. W. (2009). Planning in the USA. Policies, issues, and processes (3. painos). Lontoo ja New York: Routledge.

Ekroos, A., Katajamäki, H., Kinnunen, H., Lehtovuori, P. \& Staffans, A. (2018). Maankäytön ja rakentamisen ohjauksen uudistaminen. Ympäristöministeriön raportteja 7/2018. Helsinki: Ympäristöministeriö.

Elliot, D. L. (2008). A better way to zone. Ten Principles to create more livable cities. Washington, DC: Island Press.

Etzioni, A. (1967). Mixed-scanning: A “third" approach to decision-making. Public Administration Review, 27(5), 385-392. DOI:10.2307/973394

European Commission. (1997). The EU compendium of spatial planning systems and policies. Regional development studies 28. Luxemburg: Office for official publications of the European communities.

Friedmann, J. (2004). Strategic spatial planning and the longer range. Planning Theory \& Practice, 5(1), 49-67. DOI: 10.1080/1464935042000185062

Getimis, P. (2012). Comparing spatial planning systems and planning cultures in Europe. The need for a multi-scalar approach. Planning Practice and Research, 27(1), 25-4O. DOI: 10.1080/02697459.2012.659520

Godschalk, D. R. \& Rouse, D. C. (2015). Sustaining places. Best practices for comprehensive plans. PAS report 578. Chicago: American Planning Association.

Granqvist, K., Mäntysalo, R., Mattila, H., Hirvensalo, A., Teerikangas, S. \& Kalliomäki, H. (2019). Kaupungin strateginen spatiaalinen suunnittelu: Navigointia eri mittakaavatasojen ja rationaliteettien välillä. Yhdyskuntasuunnittelu, 57(1): 11-25. DOI: 10.33357/ys.80322

Granqvist, K., Mattila, H., Mäntysalo, R., Hirvensalo, A, Teerikangas, S. \& Kalliomäki, H. (2021). Multiple dimensions of strategic spatial planning: Local authorities navigating between rationalities in competitive and collaborative settings. Planning Theory and Practice 22(2), 173-190. DOI: 10.1080/14649357.2021.1904148

Hastio, P., Korkala, P., Laitio, M., Manninen, R., Paajanen, P. \& Palomäki, J. (2018). Yleiskaavoituksen uusimpia tuulia Lahdessa, Oulussa, Tampereella ja Helsingissä vuonna 2017. Ympäristöministeriön raportteja 2/2018. Helsinki: Ympäristöministeriö. 
Healey, P. (2007). Urban complexity and spatial strategies. Towards relational planning of our times. Oxon: Routledge.

Healey, P. (2012). The universal and the contingent: Some reflections on the transnational flow of planning ideas and practices. Planning Theory, 11(2), 188-207. DOI: 10.1177/1473095211419333

Healey, P., Khakee, A., Motte, A. \& Needham, B. (1997). Making strategic spatial plans. Innovation in Europe. Lontoo: UCL Press.

Healey, P. \& Upton, R. (toim.) (2010). Crossing borders: International exchange and planning practices. London and New York: Routledge.

Heinilä, A. (2017). Oikeus rakentaa. Tutkimus suunnittelutarveratkaisu- ja poikkeamispäätöksenteosta maankäyttö- ja rakennuslain järjestelmässä. Suomalaisen lakimiesyhdistyksen julkaisuja A 337. Helsinki: Suomalainen lakimiesyhdistys.

Hirt, S. (2012). Mixed use by default: How the Europeans (don't) zone. Journal of Planning Literature, 27(4), 375-393. DOI: $10.1177 / 0885412212451029$

Hirt. S. (2014). Zoned in the USA. The origins and implications of American land-use regulation. Ithaca, NY: Cornell University Press.

Hurmeranta, M. (2013). Kaavoihin kangistuneet - Tusina ratkaisua kaavoituksen hitauteen ja tehottomuuteen. Helsinki: Elinkeinoelämän valtuuskunta/Taloustieto.

Husa, J. (2010). Valkoista yksisarvista pyydystämässä vai mörköä paossa - "oikeaa oikeusvertailua"? Lakimies 5/2010, 700-718.

Husa, J. (2012). The stories we tell ourselves - about Nordic law in specific. https://www.edilex.fi/ artikkelit/806o (viitattu 26.10.2020).

Hytönen, J. \& Ahlqvist, T. (2019). Emerging vacuums of strategic planning: an exploration of reforms in Finnish spatial planning. European Planning Studies, 27(7), 1350-1368. DOI: 10.1080/09654313.2019.1580248

Hytönen, J., Mäntysalo, R., Peltonen, L., Kanninen, V., Niemi, P. \& Simanainen, M. (2016). Defensive routines in land use policy steering in Finnish urban regions. European Urban and Regional Studies, 23(1), 40-55. DOI: $10.1177 / 0969776413490424$

Janssen-Jansen L. B. \& Hutton, T. A. (2011). Rethinking the metropolis: Reconfiguring the governance structures of the twenty-first-century city-region. International Planning Studies, 16(3), 201-215. DOI: $10.1080 / 13563475.2011 .591140$

Kalliomäki, H. (2018). Re-contextualising Oregon's Urban Growth Boundary to city-regional planning in Tampere, Finland: The need for strategic bridge-building. Planning Theory \& Practice, 19(4), 514-533. DOI: $10.1080 / 14649357.2018 .1504980$

Kaufman, J. L. \& Jacobs, H. M. (1987). A public planning perspective on strategic planning. Journal of the American Planning Association, 53:1, 23-33. DOI: 10.1080/01944368708976632

Kelly, E. D. (2010). Community planning: An introduction to the comprehensive plan (2. painos). Washington: Island Press.

Kilpailu- ja kuluttajavirasto. (2013). Asuntotuotannon kilpailun esteet pääkaupunkiseudulla. Loppuraportti. Kilpailu- ja kuluttajaviraston selvityksiä 1/2013. Helsinki: Kilpailu- ja kuluttajavirasto.

Koivu, V.-P., Korkala, P., Laitio, M., Manninen, R., Paajanen, P., Palomäki, J., Rossi, L. \& Vänskä, V. (2013). Yleiskaavoituksen uusia tuulia. Ympäristöministeriön raportteja 10/2013. Helsinki: Ympäristöministeriö.

Kokousmuistio, MRL-uudistus / työryhmän 17. kokous. 6.2.2020. Ympäristöministeriö. https://api. hankeikkuna.fi/asiakirjat/6df1d533-c7oe-4f34-81f9-b7e932433d84/8c8b9c76-bda2-43a2-a29e13b177573a47/MUISTIO_20200423101327.pdf (viitattu 31.5.2021)

Kokousmuistio, MRL-uudistus / työryhmän 21. kokous. 16.6.2020. Ympäristöministeriö. https://api. hankeikkuna.fi/asiakirjat/6df1d533-c7oe-4f34-81f9-b7e932433d84/443obd18-0462-4f19-843abf68od953e26/MUISTIO_20200624114448.pdf (viitattu 31.5.2021)

Kuntalaki. (410/2015). https://www.finlex.fi/fi/laki/alkup/2015/20150410\#Pidp446245472 (viitattu 26.10.2020). 
Kuntaliitto. (2020). Kuntakaavasimulaatio. Loppuraportti 28.2.2020. Kuntaliitto, alueet ja yhdyskunnat. https://www.kuntaliitto.fi/sites/default/files/media/file/Kuntakaavasimulaatio_ loppuraportti_28022020_o_2.pdf (viitattu 26.10.2020).

Laitio, M. \& Maijala, O. (2010). Alueidenkäytön strateginen ohjaaminen. Suomen ympäristö 28/2010. Helsinki: Ympäristöministeriö.

Lehtovuori, P., Ekroos, A., Kuusela, K., Rantanen, A., Rajaniemi, J. \& Schmidt-Thomé, K. (2019). Tulevaisuuskatsaus eräiden maiden alueidenkäytön suunnittelujärjestelmiin. Ympäristöministeriön julkaisuja 24/2019. Helsinki: Ympäristöministeriö.

Lehtovuori, P. \& Rajaniemi, J. (2021). Maankäyttölainsäädännön muutos nyt: uudistuksesta päivitykseen. Rakennettu ympäristö 1-2/2021, 29-33.

Leino, H. \& Maununaho, K. (2020). Arkkitehtien yhteisölliset ideat eivät näy kaupunkikuvassa. Vieraskynä. Helsingin Sanomat 12.10.2020.

Loikkanen, H. A. (2013). Kaupunkialueiden maankäyttö ja taloudellinen kehitys: maapolitiikan vaikutuksista tuottavuuteen sekä työ-ja asuntomarkkinoiden toimivuuteen. VATT Valmisteluraportit 17/2013. Helsinki: Valtion taloudellinen tutkimuskeskus.

Maankäyttö- ja rakennuslaki. (132/1999). https://www.finlex.fi/fi/laki/ajantasa/1999/19990132 (viitattu 26.10.2020).

Maisala, P. (2014). Englanti ja toisenlaisen kaavoitusjärjestelmän kehittyminen. Yhdyskuntasuunnittelu, 52(1), 69-9o.

Maisala, P. (2015). Markkinoihin sopeutuvan maankäytön ohjausjärjestelmän esimerkkitapaus. Yhdyskuntasuunnittelu, 53(4), 62-75.

Mattila, H. (2017). Balancing between efficiency and sustainability. Discourses around Finnish land-use planning system. Teoksessa S. Kristjansdottir (toim.), Sustainable Planning Policy and Practice. Nordic Experiences. Lontoo: Routledge.

Mattila, H. (2018a). Public participation and legitimacy management in planning: A Habermasian perspective to Finnish welfarist planning tradition. Geografiska Annaler, series B. Human Geography, 100(4): 309-328. DOI: 10.1080/04353684.2018.1481347

Mattila, H. (2018b). The "aesthetic turn" as a bridge between communicative and agonist planning theories. Exploring the interplay of "consensus" and "dissensus" with a view on its implications for Finnish planning. Architectural Research in Finland, 2(1), 94-113. https://journal.fi/architecturalresearchfinland/ article/view/73176 (viitattu 3.11.2021).

Mazza, L. (2013). If strategic "planning is everything, maybe it's nothing". DisP-The Planning Review, 49(3), 40-42. DOI: $10.1080 / 02513625.2013 .859006$

Miller, B. (2009). Plans that fit the purpose. Teoksessa G. Hack, E. L. Birch, P. H. Sedway \& M. J. Silver (toim.), Local planning: Contemporary principles and practice. Washington D.C.: ICMA Press.

Minneapolis 2040 Policies. https://minneapolis2040.com/policies/ (viitattu 31.5.2021)

Mintzberg, H. (1994). The rise and fall of strategic planning. New York: Prentice Hill.

Moga, S. T. (2017). The zoning map and American city form. Journal of Planning Education and Research, 37(3), 271-285. DOI: 10.1177/0739456X16654277

MRL-uudistuksen tilannekatsaus 28.9.2020. Ympäristöministeriö. https://mrluudistus.fi/wp-content/ uploads/2020/10/MRL-uudistus-28-09-2020.pdf

Mäntysalo, R. \& Saglie, I.-L. (2010) Private influence preceding public involvement: Strategies for legitimizing preliminary partnership arrangements in urban housing planning in Norway and Finland. Planning Theory \& Practice, 11(3), 317-338. DOI:10.1080/14649357.2010.500123

Mäntysalo, R. \& Jarenko, K. (2012). Strategisen maankäytön suunnittelun legitimaation haaste maankäyttöja rakennuslaille. Teoksessa M. Airaksinen, H.-L. Hentilä, J. S. Jauhiainen, R. Mäntysalo \& K. Jarenko, T. Määttä, M. Pentti, J. Similä \& A. Staffans, Katsauksia maankäyttö- ja rakennuslain toimivuuteen. Ympäristöministeriön raportteja 4/2012. Helsinki: Ympäristöministeriö.

Mäntysalo, R., Kangasoja, J. K. \& Kanninen, V. (2015). The paradox of strategic spatial planning: A theoretical outline with a view on Finland. Planning Theory \& Practice, 16(2), 169-183. DOI: 10.1080/14649357.2015.1016548 
Mäntysalo, R., Tuomisaari, J., Granqvist, K. \& Kanninen, V. (2019). The strategic incrementalism of Lahti master planning: Three lessons. Planning Theory \& Practice, 20:4, 555-572. DOI: $10.1080 / 14649357.2019 .1652336$

Nadin, V. (2012). International comparative planning methodology: Introduction to the theme issue. Planning Practice \& Research, 27(1), 1-5. DOI: 10.1080/02697459.2012.669928

Nadin, V. \& Stead, D. (2013). Opening up the compendium: An evaluation of international comparative planning research methodologies European Planning Studies, 21(10), 1542-1561. DOI: $10.1080 / 09654313.2012 .722958$

Newman, P. \& Thornley, A. (1996). Urban planning in Europe. International competition, national systems and planning projects. Routledge: Lontoo ja New York.

Nykänen, K. (2021). Lapsia pesuveden mukana: Huomioita maankäyttö- ja rakennuslain uudistuksesta. Yhdyskuntasuunnittelu, 58(3), 37-41. DOI: 10.33357/ys.102711

Nyman, K. \& Mäntysalo, R. (2014). Patologisia piirteitä maankäyttö- ja rakennuslain sovelluksissa: Tapaus Savonlinnan Kasinonsaari. Kunnallistieteellinen aikakauskirja 3/14, 324-339.

Othengrafen, F. \& Galland, D. (2019). International comparative planning. Teoksessa N. Green Leigh, S. P. French, S. Guhathakurta, B. Stiftel, J. Doyle (toim.), The Routledge Handbook of International Planning Education, ss. 217-226. New York: Routledge.

Peddle, M. T. \& Lewis, J. L. (1996). Development exactions as growth management and local infrastructure finance tools. Public Works Management \& Policy, 1(2), 129-144. DOI: 10.1177/1087724X9600100203

Puustinen, S., Hirvonen, J., Niemi, P. \& Mäntysalo, R. (2013). Selvitys alueidenkäytön suunnittelun ja ohjauksen voimavaroista. Ympäristöministeriön raportteja 22/2013. Helsinki: Ympäristöministeriö.

Qian, Z. (2010). Without zoning. Urban development and land use controls in Houston. Cities 27(1), 33-41.

Ravetz, J. (2013). City-region 2020: Integrated planning for a sustainable environment. Milton Park \& New York: Routledge.

Saarela, S.-R., Strandell, A., Saastamoinen, U., Rehunen, A., Jantunen, J. \& Oinonen, K. (2019). Maankäyttöja rakennuslain kokonaisuudistus. Alueidenkäytön suunnittelujärjestelmän vaihtoehtojen alustava vaikutusten arviointi. Suomen ympäristökeskus. 6.5.2019.

Salkin, P. E. (2009). The authority to plan. Teoksessa G. Hack, E. L. Birch, P. H. Sedway \& M. J. Silver (toim.) Local Planning: Contemporary Principles and Practice. Washington D.C.: ICMA Press.

Sullivan, E. J. (2004). Comprehensive planning. The Urban Lawyer, 36(3), 541-555.

Sullivan, E. J. (2014). Urban growth management in Portland, Oregon. Oregon Law Review, 93(2), 455-498.

Tarlock, A. D. (2014). Zoned not planned. Planning Theory, 13(1), 99-112. DOI: 10.1177/1473095212469942

Taylor, Z. (2019). Pathways to legitimacy. Planning Theory, 18(2), 214-236. DOI: 10.1177/1473095218806929

Trickey, E. (2019). How Minneapolis freed Itself from the stranglehold of single-family homes. Politico Magazine. 11.7.2019. https://www.politico.com/magazine/story/2019/o7/11/housing-crisis-singlefamily-homes-policy-227265/ (viitattu 31.5.2021)

Weiss, M. A. (1992). Skyscraper zoning: New York's pioneering role. Journal of the American Planning Association, 58(2), 201-212. DOI: 10.1080/01944369208975794

Wheeler, S. M. (2000). Planning for metropolitan sustainability. Journal of planning education and research, $20(2), 133-145$.

Ympäristöministeriö. (2014). Arviointi maankäyttö- ja rakennuslain toimivuudesta 2013. Suomen ympäristö 1/2014. Helsinki: Ympäristöministeriö.

Ympäristöministeriö. (2018). Keskustelupaperi maankäyttö- ja rakennuslain uudistamisen suuntaviivoiksi. Luonnos 12.4.2018. https://www.ym.fi/download/noname/\%7B221ACCBE-9D43-4424-B74D$\mathrm{BE}_{5} \mathrm{BC} 07 \mathrm{FCB} 46 \% 7 \mathrm{D} / 136705$ (viitattu 30.5.2021)

Ziafati Bafarasat, A. (2015). Reflections on the three schools of thought on strategic spatial planning. Journal of Planning Literature, 30(2), 132-148. DOI: 10.1177/0885412214562428 